\title{
Help Me TripAdvisor! Examining the Relationship between TripAdvisor e-WOM Attributes, Trusts towards Online Reviews and Travellers Behavioural Intentions
}

\author{
Nur Zarifah Dhabitah Mahat \\ Tour Consultant, ZD Travel Consultant \\ Negeri Sembilan, Malaysia \\ Mohd Hafiz Hanafiah* \\ Faculty of Hotel and Tourism Management \\ Universiti Teknologi MARA, Malaysia
}

zarifahdhabitah@gmail.com

hafizhanafiah@uitm.edu.my

\begin{abstract}
This paper aims to examine the impact of TripAdvisor reviews on behavioural intentions, basing on travellers' trust towards the e-WOM reviews. Four factors are proposed for building travellers' trust and behavioural intentions: information quality, credibility, adoption and usefulness. Trust is expected to mediate the relationship between eWOM attributes and travellers' behavioural intention. Data from 410 travellers were analysed using Partial Least Square-Structural Equation Modeling (PLS-SEM), and the findings show that TripAdvisor e-WOM attributes (information credibility, adoption and usefulness) significantly influence the traveller's trust. Besides, traveller behavioural intention was influenced considerably by TripAdvisor eWOM information credibility and usefulness. Lastly, trust in e-WOM significantly mediates travellers' behavioural intention. This paper confirms the importance of eWOM in the context of the tourism industry and travellers' trust and behaviour towards online review, which altered how consumers behave before deciding to travel.

Keywords: electronic word of mouth (e-WOM); online reviews; trust; behavioural intention; TripAdvisor
\end{abstract}

\section{Introduction}

The emergence of social media enabled consumers to communicate without conventional barriers [1-3]. Travellers are using the social media platform to inform them about tourism-related products. Chang, $\mathrm{Ku}$, and Chen [4] and Trusov, Bodapati, and Bucklin [5] revealed that the increasing number of social media platforms nowadays has led to the explosion of online reviews and opinions. Consumers have been allowed to share their experiences through social media apps such as Facebook, Twitter, Instagram, etc. Besides, there is a massive growth of online consumer review on different travel-related services in these platforms [6]. Because of this growing 
number, tourism businesses have started to engage with social media platforms to build networks with their current and potential consumers. Various travel-related websites and apps have been developed that specialise in the tourism and hospitality industry, such as TripAdvisor, Travelocity, Expedia, etc. [7]. Currently, TripAdvisor is the world's largest travel platform with millions of traveller reviews and opinions. TripAdvisor serves as the world's top travel website and is perceived by consumers as a useful tool and source of information to obtain opinions before planning for their upcoming trip [8].

Previous studies on electronic word of mouth (e-WOM) [7, 9-11] have reported that there has been an increasing number of travellers who rely on online review to plan for their trips. As a vast amount of information on social media is available to the consumers; therefore, there is a need to carefully examine which e-WOM information is more influential to consumers [12]. Numerous studies have also been carried out relating to the e-WOM impact on tourism industry [13-17]. Most of the study proposes that the key attributes of e-WOM are information quality, information credibility and information adoption [13-17]. However, these researchers failed to anticipate which of the e-WOM attributes are more influential to the consumers [1].

Trust and e-WOM are considered as an emerging study for tourism marketers. It has been generally accepted for a long time that trust is considered as an essential tool in forming long-term consumer relationship [18]. A research done by Nicolaou and McKnight [19] showed that the majority of consumers trusted former consumers' opinions offline and online. However, there has been a growing concern about the existence of many fake reviews on social media sites. With the appearance of these phoney reviews in the online platforms, it would influence how consumer perceived and trust online reviews [20-24]. However, even though the influence of trust on customer loyalty has been examined widely, only a few studies have been carried out to determine the influence of trust in social media context [7, 18-19].

\section{Literature Review}

\section{1. e-WOM}

With the advent of technology on the Internet and communication, the consumers have the chance to share their opinions and experiences via online reviews. Online reviews are considered as the evaluations of the product and services which are provided by the service provider themselves or the third-party website [25-27]. The advent of internet technology has enabled online recommendation and sharing experiences by consumers, and this has been one of the most effective tools for consumers these days $[13,24,28]$. This has led to the new definition of word of mouth (WOM) known as the electronic word of mouth (e-WOM) [28].

According to Kietzmann and Canhoto [14], e-WOM can be defined as a platform by which the consumers share about the products/services they brought in terms of what they think and what they have experienced via the Internet such as social media or websites. Satisfied consumers may share a positive review, while the unsatisfied consumers may transcribe negative reviews $[16,29,30]$. According to Duan et al. 
[31], online reviews are one of the most powerful online tools being recommended, marketers. Moreover, the advent of e-WOM has driven the changes in consumer searching and buying products or services [32-34]. Therefore, with the growing number of e-WOM users and the increasing trend of technological people, the impact of e-WOM has become a critical field to be studied [35].

The Internet has facilitated e-WOM communication through a wide choice of platform. The way people communicate these days has changed due to the emergence of social media website $[1,15]$. Recently, social media websites have become among the popular sites for consumers. Social media is the internet-based services by which consumers can sign up their profiles and socialise around with other consumers [36]. As per Kaplan and Haenlein [2], social media is defined as Internet-based applications, which can allow the consumers' sharing on their personal experiences. There is a varied choice of social media platforms: Facebook, Twitter, YouTube, etc.

Specifically, in the tourism industry, TripAdvisor can be considered as one of the popular online review sites among avid travellers [37]. Most of the TripAdvisor users have been inspired to visit a new destination, influenced by the TripAdvisor' reviews and recommendation $[2,36]$. The greater the volume of eWoM, the more likely a consumer will be able to aware of a product or service $[5,15]$. In other research done by Herrero et al. [38], they found that content-rich information of consumers' review may affect the behaviour of other consumers. Still, what happens when consumers confronted with numerous and differentiated reviews? How do consumers deal with the dynamic and unique attributes of e-WoM? Thus, in order to better understand tourists' behaviour towards e-WOM, it is crucial to study what types of e-WOM attributes are more helpful in assisting tourists' travel behaviour and purchasing decisions.

Most of the study proposes four main attributes of e-WOM. They are information quality, information credibility and information adoption [13-17]. The next section will introduce and justify the importance of each attribute on e-WOM.

\subsection{Information Quality}

Information quality has been defined as the information in an online review and content posted by consumers in the online review based on the perspectives of information characteristic [37, 39]. Researchers defined information quality in eWOM as the reflection of relevance, sufficient, accuracy, currency [39], a reflection of value [37], a reflection of credibility and usefulness [40]. Besides, information quality has an essential cause of user trust in commercial websites [14] in the information of health [17], and it enables the transition of data [19].

According to Filieri and McLeay [37], information quality has been found to foresee information adoption and purchase intentions. The consumers used the information from the online review to decide on their purchase decision. However, it is a bit complex in choosing which destination to visit, as the travel activity contains various products and services such as lodging, carriage/transport, attractions, car rental, etc. Thus, the consumer needs to collect a tremendous amount of information before they can make a purchase. Moreover, each consumer may not share the same 
interest; as they have different travel needs and wants. These issues have been studied by Cheung et al. [40], and the findings show tourist tend to consider available information before making the decision [11].

A study done by $\mathrm{Chu}$ [41] indicated that social media had enabled tourists to write and read reviews and even give ratings to evaluate their travel experience. The rating gauges their opinion on the quality of the services, and it allows others to rate the quality of the shared review. This can be proven by the previous research by Xie, $\mathrm{Chen}$, and $\mathrm{Wu}$ [42], which claimed that ratings could be closely assimilated to the service evaluation. The review quality is the reflection on how good or bad the services, products or the destinations where the former consumers themselves make the evaluations. They will have the intention to purchase, visit or share the information if they find that the review quality is high, and they would ignore the information if the review quality is low [43].

Meanwhile, the consumer's initial trust has been found as one of the factors affected by information quality [44]. The inaccurate and irrelevant information provided would instigate the consumers to spend more time in analysing the information $[45,46]$. The information which provides quality on the topic discussed seems to be more acceptable than an outdated source. Besides, the availability of quality information online helps to shape travellers' trust towards the tourism providers $[19,30,40]$. Therefore, this study aims to explore the influence of information quality towards consumers purchase intention. From the above arguments, this study proposes the following hypotheses:

$\mathrm{H}_{1 \mathrm{a}}$ : Information quality affects travellers' behavioural intentions

$\mathrm{H}_{2 \mathrm{a}}$ : Information quality affects travellers' trust

\subsection{Information Credibility}

One of the central predictors of consumers' acceptance with traditional WOM is the credibility of the information source $[47,48]$. WOM consumers cannot adopt paraverbal communication to access the credibility of a communication source $[49,50]$. Similarly, the credibility of the sources in e-WOM communication is considered as tricky because the reviews have been written by someone whom the consumers might not know at all [16]. Thu, credibility plays vital roles in social media in which online reviews usually come from people we might not be familiar at all.

Research by Cheung et al. [40], Filieri [11], and Willemsen et al. [51] explored the influence of source credibility and trust in websites based on e-WOM. All of them proposed that lack of reviewers' information will affect the credibility of the information. The reviews with high credibility of e-WOM are often found to be more persuasive compared to those with lower or no credibility $[8,40]$. In addition, Ayeh, $\mathrm{Au}$, and Law [8] study also discovered a non-significant relationship between information credibility and intention to use user-generated information for purchase intention. Thus, as normal practice, social media website or online user generator requires consumers to sign up their profile and share their personal information and only after that the consumers are enabled to assess the credibility of other consumers in the social media [40]. 
The information credibility would lessen if tourists perceived that the online review includes irrelevant information; thus, negatively influence their trust towards the reviews [52-54]. Former tourists' reviews were found to be more credible than any information provided by tourism marketers $[55,56]$. TripAdvisor itself has introduced a system which declares that only credible reviews will be awarded in their profile and can be seen by other users so that it shows that their information is valuable. According to Park et al. [39], tourists who read credible reviews have more confidence and trust to make a booking decision since it can reduce the feelings of uncertainty. Trust and disbelief issues among consumers who read online recommendations have their grounds because of the anonymity provided by social media $[18,54,57]$. From the above arguments, this study proposes the following hypotheses:

$\mathrm{H}_{1 \mathrm{~b}}$ : Information credibility affects travellers' behavioural intentions.

$\mathrm{H}_{2 \mathrm{~b}}$ : Information credibility affects travellers' trust.

\subsection{Information Usefulness}

Another e-WOM attribute that affects consumers' purchase intentions is information usefulness [58]. The component of information usefulness was first proposed by Sussman and Siegal [59] in online consumer behavioural studies. Nowadays, most of the review website has provided a peer-reviewing system that allows consumers to upvote a review which is found to be more useful in their purchase decision while to downvote the ones which are not. For example, TripAdvisor allows the consumer to rate the reviews; serves as an indicator for online review usefulness but is also a signalling reminder for consumers to filter numerous reviews efficiently $[25,27]$. The tourist believes if the reviews are valuable, it should be a reliable review unless it cannot be useful for them [60, 61]. Thus, Cheung et al. [62], Chiang and Jang [63] and $\mathrm{Xia}$ and Bechwati [43] proposed that it is essential to gauge the relationship between information usefulness and purchase intention

Meanwhile, Gupta and Harris [64] found that the information usefulness in the online review can assist consumers in building trust in the sources. The possibility for consumers to commit can be increased when the information is useful, as it will enhance their trust in making the purchase decision. A recent study by Casaló et al. [65] explored on the perceived usefulness on the degree to which tourists believe that information presented in the online review is useful and found to be trustworthy which will consequently help them in making the travel decision [52-54]. This study aims to explore the influence of information usefulness towards travellers' behavioural intention. From the above arguments, this study proposes the following hypotheses:

$\mathrm{H}_{1 \mathrm{c}}$ : Information usefulness affects travellers' behavioural intention

$\mathrm{H}_{2 \mathrm{c}}$ : Information usefulness affects travellers' trust

\subsection{Information Adoption}

Sussman and Siegal [59] study explored how consumers adopt the information and transcribe it into action behaviour. If a consumer has a deep and cautious consideration of the information, the information influence occurs in the dominant route. Contrarily, 
if the consumer has only a little thought on the information, the information influence occurs only in the bordering route. According to Briñol et al. [66], a reliable source will lead consumers to adopt information with unfairness. The perceived usefulness effect on the relationship between argument quality and source credibility had been widely tested, especially in the Information Adoption Model (IAM), Theory of Reasoned Action (TRA) and Technology Acceptance Model (TAM).

Moreover, the impact of individuals in receiving and adopting the information and thoughts had been integrated into the Elaboration Likelihood Model (ELM). According to Cheung et al. [62], information adoption is an essential construct of IAM. Erkan and Evans [1] argued that information adoption would be affected by the attributes of information published in the sites. Thus, the consumers' attitude in the adoption of the information should be put into consideration in consumer behavioural studies.

Next, trust is essential when travellers interact with the online recommendation for the first time, and they have a limited understanding of the available tourism product and services. Tourist perceptions of doubt and risk in using online review are particularly prominent $[67,68]$, and if they do not have initial trust towards an online recommendation, they will not adopt the information but rather will search for another information sources $[69,70]$. Thus, this study aims to examine the influence of information adoption towards purchase intention. From the above arguments, this study proposes the following hypotheses:

$\mathrm{H}_{1 \mathrm{~d}}$ : Information adoption affects travellers' behavioural intentions

$\mathrm{H}_{2 \mathrm{~d}}$ : Information adoption affects travellers' trust

\subsection{Trust}

Trust in the context of social networks is another dimension that is worth the consideration in the conceptualisation of consumers' purchase intention to engage in e-WOM. Trust revolves around a framework of the confidence with the belief attitude intention as suggested by Fishbein and Ajzen [71], where the consumers perceive that the e-WOM would benefit them in any way. Casaló et al. [65] found that trust (e.g., honesty and kindness) is an important dimension that generates confidence and would influence purchase behaviour. Trust would also reflect consumers' confidence in a way that the information provided by e-WOM will fulfil their expectation [64].

Numerous studies have suggested trust as serving an important role in exchanging the information with the consumers while evaluating their purchase intentions $[18,54$, $69,72]$. The capability of trust has been having been highlighted in various tourism studies. Most of them claimed that trust is essential in tourism products and services as they are intangible and would not be able to be experienced until the products and services have been used or utilised [40,73]. Notable, Casaló et al. [64] claimed that there is always doubt in the mind of the travellers, which affects the sense of curiosity. Hence, to minimise the risks taken as travellers, most of the travellers will rely on online review information. Yoo and Gretzel [74] have revealed that modern travellers have intensively used the online review to plan their trips, and they trust e-WOM more compared to the conventional destination agents. 
Social media has been perceived by consumers as a more reliable source of information to decide their purchase intention. As there is limited study on trust in social media review, the outcome of the research can support these findings by Awad and Ragowsky [75] regarding the trust and self-confidence in social media. Thus, this study proposed that the trust with e-WOM would affect travellers' purchase intention $[18,37,68,73]$. From the above arguments, this study proposes the following hypotheses

$\mathrm{H}_{3}$ : Trust affects travellers' behavioural intentions

\subsection{Mediating effect of Trust}

Social media is struggling to maintain a long-term customer relationship due to the increasing number of trust issue. According to Romaniuk and Sharp [76], and Fam et al. [77], they suggested that social media platform would positively affect the consumers' behavioural intention in purchase decision if they trust the platform. It is believed that without trust, the consumer will never have the intention to follow or adapt whatever that is written in the social media platform [54, 72, 75]. A wellestablish social media platform can positively affect consumer's trust and behavioural intention, as stated by Fam et al. [76]. Nevertheless, while most of the study has explored trust as the independent variable, a minimal study has been done on trust as which acts as the mediating variable in finding the relationship between e-WOM determinants and consumer' behavioural intention.

Meanwhile, Park et al. [39] and Luo et al. [57] have found in their study that the information quality will affect the consumers' trust on behavioural intention. For example, when the consumer plan to go somewhere and looking for information through the social media platform, they will look at the quality of information shared in the review first before they tend to adopt it. Their study also found numerous characteristics of online information such as information quantity, information credibility and information quality. A study has been conducted on a literature review of e-WOM characteristics to explain the impact of e-WOM on tourists' behaviour [58]. Meanwhile, Cheung et al. [62] explored how information credibility and information quality as the main e-WOM determinants could encourage tourist trust to have the willingness to adopt online review.

According to Cheung et al. [57], information credibility refers to the extent to which the trust that consumers have in reviews they read on the website. The credibility can play an important role in social media platform because reviews on social media are usually anonymous. The anonymity can cause distrust in online recommendation among consumers [47, 48, 57, 73]. Thus, when tourists trust the social media platform, they will be more prone to trust the information sharing and will constantly use the platform to plan for their trip. From the above arguments, this study proposes the following hypotheses;

$\mathrm{H}_{4 \mathrm{a}}$ : Trust mediates the relationship between information quality and travellers' behavioural intentions

$\mathrm{H}_{4 \mathrm{~b}}$ : Trust mediates the relationship between information credibility and travellers' behavioural intentions 
$\mathrm{H}_{4 \mathrm{c}}$ : Trust mediates the relationship between information usefulness and travellers' behavioural intentions

$\mathrm{H}_{4 \mathrm{~d}}$ : Trust mediates the relationship between information adoption and travellers' behavioural intentions

\section{Method}

\subsection{Research Design}

This study adopts the cross-sectional concept in which data will be gathered just once over a certain period to answer the research questions [78]. This study was conducted in a non-contrived setting with slight interferences of the researcher. The unit analysis for this study is a tourist who already has undergone the experience of reading TripAdvisor reviews of KLCC before deciding to visit KLCC. The sample size has been determined based on Krejcie and Morgan [79] sample size table. The sample size for this research is 384 travellers. This study opts convenience sampling as the method of sampling design. It refers to the collection of data from subjects who are conveniently available at a selected venue at the time [77].

\subsection{Research Instruments}

This study has been conducted using questionnaires through a self-administered technique. The survey was divided into four sections. In section $\mathrm{A}$, the respondents need to answer the screening question regarding their experience of using the TripAdvisor. If a respondent answers yes, he or she will be asked to proceed to answer the rest of the questionnaire, but if the respondent answers no, he or she will not be eligible to participate in the survey. The reason for the screening question is to make sure that this study obtains the appropriate respondents to participate in the survey.

Section B consists of the demographic profile (gender, age, frequency of travel, frequency of using TripAdvisor website, frequency of reading the reviews on TripAdvisor and time frame in using the Internet). Meanwhile, in section $\mathrm{C}$, the visitors were asked about their perception towards the e-WOM attributes, specifically their perception towards TripAdvisor information quality, information credibility, information usefulness, information adoption. Next, this study surveyed their trust and their behavioural intentions. The survey instruments were adopted from various tourism researchers $[3,39,62,80]$.

This study employed a 5-point Likert scale. They are indicated to respond to the degree of agreement of each stimulus. In a 5-point Likert scale, every number represent separate agreement, which is 1-Strongly disagree, 2-Disagree, 3-Neutral, 4Agree, 5-Strongly agree.

\subsection{Pilot Study}

A pilot study was conducted before the final process was done. It is to measure whether the dimensions construct for the survey are acceptable or should be deleted 
in terms of appropriately used of each item. The pilot test was conducted during March 2019 until May 2019. The online survey was chosen for easier data recording. The data were coded, and the result was analysed using Cronbach Alpha for instruments reliability test. Based on the result, the Cronbach alpha values for all variables were between 0.740 to 0.924 . Since all the variables in this pilot study met the threshold of this analysis (Cronbach Alpha $>0.70$ ), it can be concluded that the measurement was reliable [81] and can be utilised for empirical research [82].

\subsection{Data Collection}

This study adopts a self-administered questionnaire. The data was collected at Kuala Lumpur City Center (KLCC) through the online survey form. Before the respondent answer the survey, they have been briefed about the study in advanced before they were given the time to fill it. The questionnaire was created with Google Forms that allowed the researcher to develop survey-style forms with questions of all different types of data in the answer fields as the survey was conducted using tablet devices instead of the paper-based questionnaire.

By using Google Forms, the researcher had set every item as compulsory. Otherwise, the respondents could not proceed to the next question, and no missing data were found throughout the entire entries. Four hundred twenty-five (425) respondents in total were obtained at the end for the data analysis process. The responses had been fed directly into a spreadsheet for coding purposes. Only 410 of them can be used for the study after data entry and cleaning procedures.

\subsection{Data Analysis}

This study adopted the Partial Least Square-Structural Equation Modelling (PLSSEM) to test the study hypotheses via the SmartPLS 3.1 software. PLS-SEM is known as the second-generation technique used in explaining possible relationships between multiple variables $[83,84]$. PLS-SEM simultaneously assess the measurement model (the relationships between constructs and measures) and the path model (the relationship between one construct and another) to test theoretical relationships. PLSSEM is particularly useful for causal-predictive analysis in situations of high complexity and low theoretical information availability [84]. PLS-SEM consists of a two-step approach. The two-step approach involves estimating the measurement model before undertaking an analysis of the structural model. The results of the analyses and findings of this study are discussed in the next section.

\section{Findings}

\subsection{Demographic Profile}

The following section presents the respondents demographic profiles. A total number of respondents who participated in this survey is 410 respondents. Table 1 below reports the demographic profile of the 410 respondents. 


\begin{tabular}{|l|l|l|}
\hline Demographic factors & Frequencies (f) & Percentage \\
\hline Frequency of reading TripAdvisor & & \\
reviews & 52 & $12.7 \%$ \\
Rarely & 108 & $26.3 \%$ \\
Often & 178 & $43.4 \%$ \\
Sometimes & 72 & $17.6 \%$ \\
Every time I plan a trip & & \\
\hline Gender & & \\
Male & 230 & $56.1 \%$ \\
Female & 180 & $43.9 \%$ \\
\hline Age & & \\
Below 20 years old & 14 & $3.4 \%$ \\
21 to 30 years old & 173 & $42.2 \%$ \\
31 to 40 years old & 114 & $27.8 \%$ \\
41 to 50 years old & 79 & $19.3 \%$ \\
51 years old and above & 30 & $7.3 \%$ \\
\hline Frequency of travel for leisure & & \\
Several times a month & 104 & $25.1 \%$ \\
Once a month & 243 & $59.3 \%$ \\
Several times a year & 59 & $14.4 \%$ \\
Once a year & 5 & $1.2 \%$ \\
\hline Timeframe of using Social Media & 10 & \\
Less than one year & 60 & $14 \%$ \\
One to three years & 78 & $19.0 \%$ \\
Four to six years & 262 & $63.9 \%$ \\
More than six years & & \\
\hline & & \\
\hline
\end{tabular}

Table 1. Demographic profile

Table 1 summarised the demographic profiles of the survey respondents. Based on the table above, the majority of the respondents are well experienced with the TripAdvisor. Majority of them to $43.4 \%(n=178)$ read TripAdvisor reviews before travelling. Majority of them were male with $56.1 \%(n=230)$ and $43.9 \%(n=180)$ were female respondents. Most of the respondents aged between 21-230 years old (42.2\%; $n=173)$ followed by respondents aged $31-40$ years old $(27.8 \% ; n=114)$. Most of the respondents usually travel for leisure at least once a month $(59.3 \% ; n=243)$ and several times a month $(25.1 \% ; n=104)$. In term of the experience in using social media, more than two-thirds of the respondents are experienced user $(63.9 \% ; n=262)$.

\subsection{Measurement model}

This study employed the SmartPLS 3.1 software and the first step is to run the measurement model analysis. Measurement model specifies that a latent or unobservable concept causes variation in a set of observable indicators, which can, therefore, be used to gain an indirect measurement of the model. Four parameters were examined: (i) internal consistency reliability, (ii) indicator reliability, (iii) convergent validity and (iv) discriminant validity [85] to examine the reflective measurement 
models. To assess the model internal consistency reliability, composite reliability (CR) was adopted. This ensures that measurements are prioritised according to their reliability about making estimations, rather than assuming that all measurements are equally reliable; this, in turn, makes it suitable for PLS-SEM [85]. A threshold value of 0.7 was adopted for the survey instruments factor loadings [86].

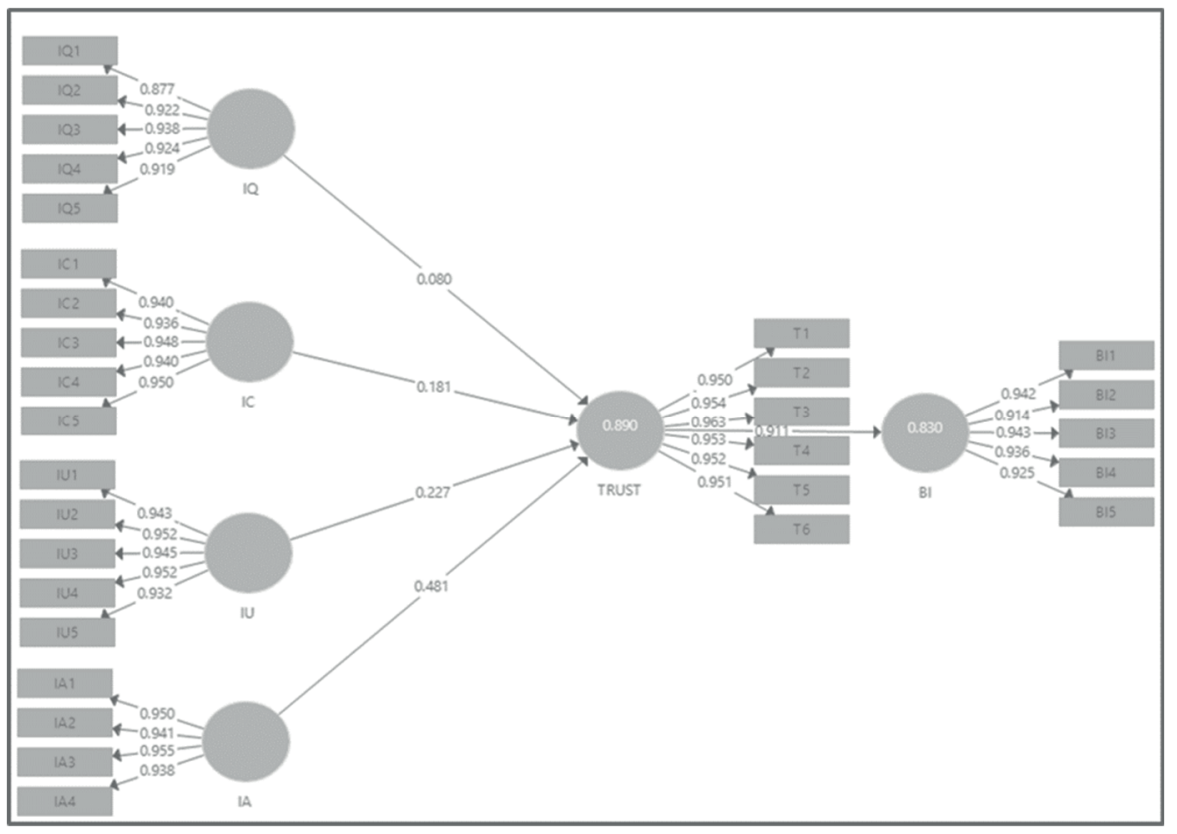

Figure 1. Measurement model

Next, convergent validity test analysed the correlation between the responses obtained through different methods which represent the same construct [87]. The convergent validity was determined using the widely accepted method: the Average Variance Extracted (AVE) [84]. The AVE value should be greater than 0.5, and the value indicates that on average, each construct is capable in explaining more than half of the variance of its measuring items [84]. Next, the discriminant validity at the construct-level was examined using Fornell and Larcker [88] criteria, while discriminant validity at the item level was examined using Chin [87] criteria. Figure 1 displays the measurement model.

Table 2 reported the outer loading, indicator reliability, composite reliability and the AVE scores for the reflective measurement model.

\begin{tabular}{|l|l|l|l|l|l|}
\hline Indicators & $\begin{array}{l}\text { Outer } \\
\text { Loadings }\end{array}$ & $\begin{array}{l}\text { Indicator } \\
\text { Reliability }\end{array}$ & $\begin{array}{l}\text { Composite } \\
\text { Reliability }\end{array}$ & AVE & $\begin{array}{l}\text { Cronbach } \\
\text { Alpha }\end{array}$ \\
\hline BI1 & 0.942 & 0.887 & $0.971 * * *$ & $0.869 * * *$ & $0.962 * * *$ \\
\hline BI2 & 0.914 & 0.835 & & & \\
\hline
\end{tabular}




\begin{tabular}{|l|l|l|l|l|l|}
\hline BI3 & 0.943 & 0.889 & & & \\
\hline BI4 & 0.936 & 0.876 & & & \\
\hline BI5 & 0.925 & 0.856 & & & \\
\hline IA1 & 0.950 & 0.903 & $0.971^{* * *}$ & $0.895^{* * *}$ & $0.961^{* * *}$ \\
\hline IA2 & 0.941 & 0.885 & & & \\
\hline IA3 & 0.955 & 0.912 & & & \\
\hline IA4 & 0.938 & 0.880 & & & \\
\hline IC1 & 0.940 & 0.884 & $0.969^{* * *}$ & $0.889^{* * *}$ & $0.969^{* * *}$ \\
\hline IC2 & 0.936 & 0.876 & & & \\
\hline IC3 & 0.948 & 0.899 & & & \\
\hline IC4 & 0.940 & 0.884 & & & \\
\hline IC5 & 0.950 & 0.903 & & & \\
\hline IQ1 & 0.877 & 0.769 & $0.952^{* * *}$ & $0.839^{* * *}$ & $0.952^{* * *}$ \\
\hline IQ2 & 0.922 & 0.850 & & & \\
\hline IQ3 & 0.938 & 0.879 & & & \\
\hline IQ4 & 0.924 & 0.854 & & & \\
\hline IQ5 & 0.919 & 0.845 & & & \\
\hline IU1 & 0.943 & 0.889 & $0.970^{* * *}$ & $0.893^{* * *}$ & $0.970^{* * *}$ \\
\hline IU2 & 0.952 & 0.906 & & & \\
\hline IU3 & 0.945 & 0.893 & & & \\
\hline IU4 & 0.952 & 0.906 & & & \\
\hline IU5 & 0.932 & 0.869 & & & \\
\hline T1 & 0.950 & 0.903 & $0.980^{* * *}$ & & \\
\hline T2 & 0.954 & 0.910 & & & \\
\hline T3 & 0.963 & 0.927 & & & \\
\hline T4 & 0.953 & 0.908 & & & \\
\hline T5 & 0.952 & 0.906 & & & \\
\hline T6 & 0.951 & 0.904 & & & \\
\hline
\end{tabular}

Table 2. Measurement model result

\subsubsection{Indicator reliability}

In assessing the reliability of each indicator, the loadings of the measures were analysed with their respective constructs generated (outer loadings). Each loading was reviewed to verify whether the individual items were reliable, and those measurement items with loadings greater than 0.7 were retained. The factor loadings from the measurement model are shown above in Table 2. The cross-loading value indicated that all eight measurement items loaded distinctly onto the specified latent variables 
they are intended to measure. Furthermore, based on the above table, all items loaded significantly (loadings ranging from 0.769 to 0.923 ) onto their respective factors, verifying their indicator reliability [88].

\subsubsection{Convergent validity}

Convergent validity was assessed based on the AVE value. In the context of this research, the AVE values of Information Quality (IQ), Information Credibility (IC), Information Usefulness (IU), Information Adoption (A), Trust and Behavioral Intention (BI) were well above the required minimum level of 0.50 . Thus, the measures of the two reflective constructs had high levels of convergent validity and exhibited high reliability. Meanwhile, the reliability of individual indicators was obtained by squaring the loading value. All the indicators for the reflective constructs were well above the minimum acceptable level (.70). In conclusion, the values in this model for factor loading, composite reliability (CR) and AVE analysis exceeded the recommended cut-off parameters. Overall, the results show that the two reflective constructs exhibit reasonable convergent validity of the measurement models proposed in this study.

\subsubsection{Fornell-Larcker criteria}

The Fornell-Larcker criteria [33] assess the discriminant validity of the construct level. It postulates that the correlation of a construct with its indicators (i.e., the square root of AVE) should exceed the correlation between the construct and any other construct's indicators [73]. Table 3 shows the result of the Fornell-Larcker [73] criteria analysis.

\begin{tabular}{|l|l|l|l|l|l|l|}
\hline & BI & IA & IC & IQ & IU & TRUST \\
\hline BI & $\mathbf{0 . 9 3 2}$ & & & & & \\
\hline IA & 0.906 & $\mathbf{0 . 9 4 6}$ & & & & \\
\hline IC & 0.921 & 0.926 & $\mathbf{0 . 9 4 3}$ & & & \\
\hline IQ & 0.891 & 0.896 & 0.924 & $\mathbf{0 . 9 1 6}$ & & \\
\hline IU & 0.913 & 0.924 & 0.923 & 0.901 & $\mathbf{0 . 9 4 5}$ & \\
\hline TRUST & 0.911 & 0.930 & 0.910 & 0.883 & 0.911 & $\mathbf{0 . 9 5 4}$ \\
\hline
\end{tabular}

Notes: BI $=$ Behavioural Intention, IA $=$ Information Adoption, IC $=$ Information Credibility, IQ = Information Quality, IU = Information Usefulness, and T $=$ Trust

Table 3. Fornell-Larcker criteria

The bolded values in Table 3 represent the square roots of the AVE, while the non-bolded values represent the intercorrelation value between constructs. Based on the above table, the off-diagonal elements are lower than the square roots of AVE (BI $=0.932, \mathrm{IA}=0.946, \mathrm{IC}=0.943, \mathrm{IQ}=0.916, \mathrm{IU}=0.945$, and $\mathrm{T}=0.954)$. Hence, the results do meet the criteria stipulated by Fornell and Larker [73]. In all cases, the root AVE values were greater than the corresponding off-diagonal correlations, indicating 
adequate discriminant validity [89]. Based on the Fornell-Larcker [73] analysis, the measurement model in this study demonstrated adequate discriminant validity, which means that all the latent variables proposed in the hypothesised model are different from each other.

\subsubsection{Cross-loadings}

Cross-loadings serve as another check for the discriminant validity of the indicator level [87]. The PLS-SEM algorithm function produces the output of cross-loadings. As per Table 4, the loading of each indicator is greater than all its other cross-loadings [90].

\begin{tabular}{|l|l|l|l|l|l|l|}
\hline & BI & IA & IC & IQ & IU & TRUST \\
\hline BI1 & $\mathbf{0 . 9 4 2}$ & 0.856 & 0.879 & 0.849 & 0.878 & 0.862 \\
\hline BI2 & $\mathbf{0 . 9 1 4}$ & 0.820 & 0.840 & 0.803 & 0.826 & 0.827 \\
\hline BI3 & $\mathbf{0 . 9 4 3}$ & 0.859 & 0.863 & 0.833 & 0.863 & 0.845 \\
\hline BI4 & $\mathbf{0 . 9 3 6}$ & 0.850 & 0.857 & 0.839 & 0.852 & 0.854 \\
\hline BI5 & $\mathbf{0 . 9 2 5}$ & 0.836 & 0.851 & 0.830 & 0.837 & 0.858 \\
\hline IA1 & 0.870 & $\mathbf{0 . 9 5 0}$ & 0.883 & 0.858 & 0.898 & 0.890 \\
\hline IA2 & 0.844 & $\mathbf{0 . 9 4 1}$ & 0.866 & 0.849 & 0.882 & 0.866 \\
\hline IA3 & 0.860 & $\mathbf{0 . 9 5 5}$ & 0.880 & 0.842 & 0.869 & 0.880 \\
\hline IA4 & 0.853 & $\mathbf{0 . 9 3 8}$ & 0.874 & 0.842 & 0.848 & 0.885 \\
\hline IC1 & 0.861 & 0.854 & $\mathbf{0 . 9 4 0}$ & 0.881 & 0.844 & 0.856 \\
\hline IC2 & 0.857 & 0.874 & $\mathbf{0 . 9 3 6}$ & 0.882 & 0.871 & 0.858 \\
\hline IC3 & 0.878 & 0.871 & $\mathbf{0 . 9 4 8}$ & 0.862 & 0.866 & 0.847 \\
\hline IC4 & 0.880 & 0.888 & $\mathbf{0 . 9 4 0}$ & 0.866 & 0.889 & 0.861 \\
\hline IC5 & 0.865 & 0.878 & $\mathbf{0 . 9 5 0}$ & 0.863 & 0.879 & 0.868 \\
\hline IQ1 & 0.768 & 0.765 & 0.784 & $\mathbf{0 . 8 7 7}$ & 0.788 & 0.743 \\
\hline IQ2 & 0.819 & 0.821 & 0.852 & $\mathbf{0 . 9 2 2}$ & 0.816 & 0.816 \\
\hline IQ3 & 0.829 & 0.837 & 0.863 & $\mathbf{0 . 9 3 8}$ & 0.841 & 0.822 \\
\hline IQ4 & 0.826 & 0.833 & 0.857 & $\mathbf{0 . 9 2 4}$ & 0.831 & 0.827 \\
\hline IQ5 & 0.839 & 0.845 & 0.871 & $\mathbf{0 . 9 1 9}$ & 0.851 & 0.833 \\
\hline IU1 & 0.851 & 0.858 & 0.863 & 0.853 & $\mathbf{0 . 9 4 3}$ & 0.834 \\
\hline IU2 & 0.869 & 0.871 & 0.880 & 0.854 & $\mathbf{0 . 9 5 2}$ & 0.869 \\
\hline IU3 & 0.863 & 0.869 & 0.861 & 0.846 & $\mathbf{0 . 9 4 5}$ & 0.861 \\
\hline IU4 & 0.874 & 0.889 & 0.889 & 0.858 & $\mathbf{0 . 9 5 2}$ & 0.878 \\
\hline IU5 & 0.858 & 0.879 & 0.867 & 0.849 & $\mathbf{0 . 9 3 2}$ & 0.861 \\
\hline T1 & 0.876 & 0.894 & 0.879 & 0.835 & 0.851 & $\mathbf{0 . 9 5 0}$ \\
\hline T2 & 0.860 & 0.886 & 0.862 & 0.844 & 0.863 & $\mathbf{0 . 9 5 4}$ \\
\hline T3 & 0.880 & 0.899 & 0.888 & 0.859 & 0.868 & $\mathbf{0 . 9 6 3}$ \\
\hline T4 & 0.855 & 0.877 & 0.847 & 0.830 & 0.875 & $\mathbf{0 . 9 5 3}$ \\
\hline T5 & 0.864 & 0.883 & 0.872 & 0.853 & 0.878 & $\mathbf{0 . 9 5 2}$ \\
\hline
\end{tabular}




\begin{tabular}{l|l|l|l|l|l|l|}
\hline T6 & 0.880 & 0.886 & 0.861 & 0.834 & 0.880 & $\mathbf{0 . 9 5 1}$ \\
\hline
\end{tabular}
Note: BI = Behavioural Intention, IA = Information Adoption, IC = Information
Credibility, IQ = Information Quality, IU = Information Usefulness, and T = Trust

Table 4. Cross-loadings

Table 4 reports the output of cross-loading between constructs and indicators. The result shows that all measurement items loaded higher concerning their intended latent variable, as compared to other variables. The table above also illustrates that the loading of each block is greater than any other block in the same rows and columns. The loadings separate each latent variable as theorised in the research framework. Thus, the cross-loading output confirms the measurement model discriminant validity, based on the second assessments [87].

\subsubsection{Summary of Measurement Model}

This study concludes that the measurement model is discriminately valid. To conclude on the reflective measurement model assessment, based on the preliminary assessments of reliability, convergent validity, and discriminant validity, the measures showed satisfactory reliability and validity. They were thereby used to estimate parameters in the structural model. Table 5 shows the final results of the measurement model assessment.

\begin{tabular}{|c|c|c|}
\hline Construct & Code & Determinants \\
\hline \multirow{5}{*}{$\begin{array}{l}\text { Information } \\
\text { Quality }\end{array}$} & IQ1 & I believe the TripAdvisor reviews are understandable \\
\hline & IQ2 & I believe the TripAdvisor reviews are reliable \\
\hline & IQ3 & $\begin{array}{l}\text { In general, I believe the quality of TripAdvisor reviews is } \\
\text { reasonable. }\end{array}$ \\
\hline & IQ4 & $\begin{array}{l}\text { I believe using TripAdvisor reviews will reduce my time } \\
\text { searching for information }\end{array}$ \\
\hline & IQ5 & $\begin{array}{l}\text { I believe TripAdvisor reviews enable me to accomplish my } \\
\text { travel plan more effectively }\end{array}$ \\
\hline \multirow[t]{5}{*}{$\begin{array}{l}\text { Information } \\
\text { Credibility }\end{array}$} & $\mathrm{IC} 1$ & $\begin{array}{l}\text { Based on the comment rating, I believe the TripAdvisor } \\
\text { reviews are trustworthy. }\end{array}$ \\
\hline & $\mathrm{IC} 2$ & $\begin{array}{l}\text { I believe the information given in the TripAdvisor reviews } \\
\text { are dependable. }\end{array}$ \\
\hline & IC3 & $\begin{array}{l}\text { I believe that consumers' recommendations on TripAdvisor } \\
\text { are accurate. }\end{array}$ \\
\hline & IC4 & $\begin{array}{l}\text { I believe that consumers' recommendations on TripAdvisor } \\
\text { are credible }\end{array}$ \\
\hline & IC5 & $\begin{array}{l}\text { I believe that review information on TripAdvisor is } \\
\text { trustworthy }\end{array}$ \\
\hline $\begin{array}{l}\text { Information } \\
\text { Usefulness }\end{array}$ & IU1 & $\begin{array}{l}\text { I believe TripAdvisor reviews improve my travel planning } \\
\text { process }\end{array}$ \\
\hline
\end{tabular}




\begin{tabular}{|c|c|c|}
\hline & IU2 & $\begin{array}{l}\text { I believe TripAdvisor reviews enhances my effectiveness in } \\
\text { searching for travel information. }\end{array}$ \\
\hline & IU3 & $\begin{array}{l}\text { I believe TripAdvisor reviews makes my travel planning } \\
\text { easier }\end{array}$ \\
\hline & IU4 & $\begin{array}{l}\text { I believe TripAdvisor reviews are useful for searching for } \\
\text { the information that I need before making my } \\
\text { reservation/decision }\end{array}$ \\
\hline & IU5 & $\begin{array}{l}\text { Overall, I believe reading TripAdvisor reviews are useful } \\
\text { before travelling }\end{array}$ \\
\hline \multirow[t]{4}{*}{$\begin{array}{l}\text { Information } \\
\text { Adoption }\end{array}$} & IA1 & $\begin{array}{l}\text { TripAdvisor reviews make it easier for me to decide to visit } \\
\text { a tourist destination. }\end{array}$ \\
\hline & IA2 & $\begin{array}{l}\text { TripAdvisor enhance my effectiveness in deciding to visit a } \\
\text { tourist destination. }\end{array}$ \\
\hline & IA3 & I usually agree with the opinion suggested in the reviews. \\
\hline & IA4 & I followed the suggestions in online reviews. \\
\hline \multirow[t]{6}{*}{ Trust } & $\mathrm{T} 1$ & $\begin{array}{l}\text { I believe that the reviews in TripAdvisor are sincere and } \\
\text { honest. }\end{array}$ \\
\hline & $\mathrm{T} 2$ & I believe the TripAdvisor reviews are reliable. \\
\hline & $\mathrm{T} 3$ & $\begin{array}{l}\text { I believe the reviews by the former consumer in TripAdvisor } \\
\text { is truthful. }\end{array}$ \\
\hline & $\mathrm{T} 4$ & $\begin{array}{l}\text { I believe the length of content in a review demonstrates the } \\
\text { degree of the reviewers' effort. }\end{array}$ \\
\hline & T5 & $\begin{array}{l}\text { I believe similar content by different reviewers verifies the } \\
\text { TripAdvisor reviews authenticity. }\end{array}$ \\
\hline & T6 & I trust the TripAdvisor reviews. \\
\hline \multirow[t]{5}{*}{$\begin{array}{l}\text { Behavioural } \\
\text { Intention }\end{array}$} & BI1 & $\begin{array}{l}\text { Before travelling, I feel secure in accepting the suggestions } \\
\text { made by the travellers in TripAdvisor }\end{array}$ \\
\hline & $\mathrm{BI} 2$ & $\begin{array}{l}\text { Before travelling, I rely on the recommendations made by } \\
\text { other travellers on TripAdvisor }\end{array}$ \\
\hline & $\mathrm{BI} 3$ & $\begin{array}{l}\text { Before travelling, I closely follow the suggestions of the } \\
\text { positive comments made by the travellers in TripAdvisor }\end{array}$ \\
\hline & BI4 & $\begin{array}{l}\text { Before travelling, I feel comfortable acting according to the } \\
\text { advice/information I obtain in TripAdvisor }\end{array}$ \\
\hline & BI5 & $\begin{array}{l}\text { Before travelling, I did not hesitate to consider the } \\
\text { comments and suggestions made by other travellers on } \\
\text { TripAdvisor }\end{array}$ \\
\hline
\end{tabular}

Table 5. Summary of Measurement Model Assessment

With satisfactory results for reliability and validity, the next stage is to perform the analysis of the structural model, to determine the explanatory power of the proposed model and to test the research hypotheses in this thesis. 


\subsection{Structural model}

Having established a reliable and valid measurement model, the next step of the analysis involved estimating the causal and covariance linear relationships among the exogenous (independent) and endogenous (dependent) latent variables. This stage aims to test all the proposed hypotheses in this study. The criteria used in assessing the PLS-SEM involved the estimation of path coefficient $(\beta)$, coefficient of determination $\left(\mathrm{R}^{2}\right)$, effect size $\left(f^{2}\right)$ and prediction relevance $\left(\mathrm{Q}^{2}\right)$ [90].

\subsubsection{Path coefficient}

The path estimation, also known as nomological validity (i.e. hypothetical relations), was performed to examine the significance of the path relations in the inner model [87].

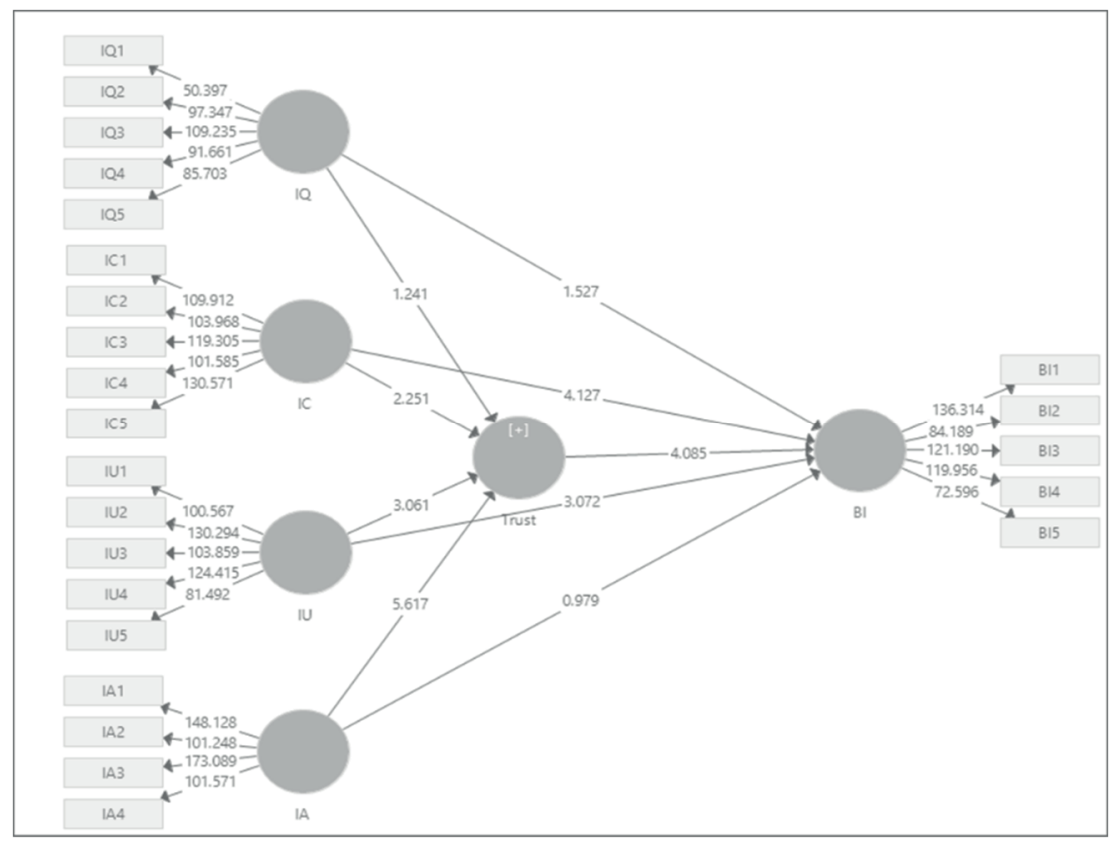

Figure 2. Structural Model

Based on the analysis conducted on the structural model, the researcher was able to confirm or disconfirm each hypothesis; it also shed insight into the strength of the relationship between dependent and independent variables.Using the SmartPLS 3.1 algorithm output, the relationships between independent and dependent variables were examined. The path relationship presented in the framework was examined through the regression beta coefficient $(\beta)$ value. The significance of the regression beta coefficient $(\beta)$ was based on the t-values, which was obtained using the SmartPLS bootstrapping process. Based on the t-statistics output, the significance of each relationship was determined. Figure 2 below shows the structural model with the 
result of path coefficients and significance levels. Table 6 reports the path coefficients, observed t-statistics and significance levels for all hypothesised path.

\begin{tabular}{|c|c|c|c|c|}
\hline & Path coefficient (B) & T-Statistics & P-Values & Results \\
\hline IA -> TRUST & $0.476^{* * *}$ & 6.163 & 0.000 & Accepted \\
\hline IC -> TRUST & $0.185^{* *}$ & 2.238 & 0.026 & Accepted \\
\hline IQ -> TRUST & 0.079 & 1.284 & 0.200 & Rejected \\
\hline IU -> TRUST & $0.230 * * *$ & 2.998 & 0.003 & Accepted \\
\hline TRUST -> BI & $0.912 * * *$ & 70.212 & 0.000 & Accepted \\
\hline IA $->$ BI & 0.064 & 0.979 & 0.328 & Rejected \\
\hline IC $->$ BI & $0.299 * * *$ & 4.127 & 0.000 & Accepted \\
\hline IQ -> BI & 0.102 & 1.527 & 0.127 & Rejected \\
\hline IU $->$ BI & $0.240 * * *$ & 3.072 & 0.000 & Accepted \\
\hline
\end{tabular}

Table 6. Path Coefficients, T-statistics and Significance Levels

Table 6 reports the path analysis. First, by treating trust as the dependent variable, the results of the path coefficients revealed that information credibility $\left(\beta=0.185^{* *}\right.$; $\mathrm{t}=2.238)$, information usefulness $(\beta=0.230 * * * ; \mathrm{t}=2.998)$ and information adoption $\left(\beta=0.476^{* * *} ; \mathrm{t}=6.163\right)$ were significant, while the information quality $(\beta=0.079$; $\mathrm{t}=1.284$ ) were found to be insignificant. The positive beta would imply that the significant independent variables (information credibility, information usefulness and information adoption) are positively influencing trust.

Meanwhile, focusing on the predictors of behavioural intention, results of the path coefficients revealed that information usefulness $(\beta=0.240 * * * ; \quad t=3.072)$ and information credibility $(\beta=0.299 * * ; t=4.127)$ were significant, while the information quality $(\beta=0.102 ; \mathrm{t}=0.127)$ and information adoption $(\beta=0.064 \mathrm{t}=0.328)$ were found to be insignificant. A positive beta would imply that the significant independent variables (information credibility and information usefulness) are positively influencing behavioural intention.

\subsubsection{Coefficient of Determination $\left(R^{2}\right)$}

The coefficient of determination $\left(\mathrm{R}^{2}\right)$ is a representation of the extent of the effect of the independent variable on the dependent variable. $\mathrm{R}^{2}$ indicates the variances of the dependent variable that can be explained by the independent variable(s). The $\mathrm{R}^{2}$ value indicates the amount of variance in the dependent variable that is explainable by the independent variables. Hair et al. [84] argued that $\mathrm{R}^{2}$ values of $0.25,0.50$ and 0.75 in the structural model of PLS-SEM analysis could be interpreted as weak, moderate and substantial, respectively. In this study, the SmartPLS algorithm function was used to obtain $\mathrm{R}^{2}$ values, while the SmartPLS bootstrapping function was used to generate $\mathrm{t}$ statistic values. Table 7 reports the coefficient of determination $\left(\mathrm{R}^{2}\right)$ and predictive relevance $\left(\mathrm{Q}^{2}\right)$ values. 


\begin{tabular}{|l|l|l|l|}
\hline Variables & R Square & R Square Adjusted & $\mathbf{Q}^{\mathbf{2}}$ \\
\hline BI & 0.830 & 0.830 & 0.427 \\
\hline Trust & 0.890 & 0.890 & 0.227 \\
\hline
\end{tabular}

Table 7. Coefficient of determination $\left(\mathrm{R}^{2}\right)$ and Predictive Relevance $\left(\mathrm{Q}^{2}\right)$

The results showed a substantial amount of variance $\left(R^{2}\right.$ values ranged from 0.830 to 0.890 ) in the behavioural intention and trust construct that can be explained by the proposed predictors. The information quality, information credibility, information usefulness and information adoption constructs were able to explain $83 \%\left(\mathrm{R}^{2}=0.830\right)$ of the variance in the behavioural intention. Additionally, the information quality, information credibility, information usefulness and information adoption constructs were able to explain $89 \%\left(\mathrm{R}^{2}=0.890\right)$ of the variance in trust. Based on the criteria put forth by Chin [87], this model was considered to be substantially fit.

\subsubsection{Predictive Relevance $\left(Q^{2}\right)$}

In addition to the size of $\mathrm{R}^{2}$, the predictive sample reuse technique $\left(\mathrm{Q}^{2}\right)$ can be effectively employed in order to assess the structural model predictive relevance [84]. Specifically, Geisser's test of predictive relevance $\left(Q^{2}\right)$ was applied to determine the predictive relevance of the independent variables in the model [91]. The $\mathrm{Q}^{2}$ value should be greater than zero to conclude that the model has predictive validity. The indices for $\mathrm{Q}^{2}$ are explained in Table 7. Using an omission distance of 0.7 , the study obtains a $\mathrm{Q}^{2}$ value of 0.227 for trust and 0.427 for behavioural intention, which is both indicative of a highly predictive model. The higher the value of $\mathrm{Q}^{2}$, the greater is the predictive relevance of the structural model.

\subsubsection{Effect Sze $\left(f^{2}\right)$}

The inner model change in the relations on the effect size is calculated by employing Chin [87] effect size function of $f^{2}$. The effect size function $\left(f^{2}\right)$, which is similar to traditional partial F-test [90], explains the increases in $\mathrm{R}^{2}$ relative to the proportion of variance of the dependent variable that remains unexplained. According to Chin [87], $f^{2}$ values of $0.02,0.15$, and 0.35 for the significant independent variables represent weak, moderate and substantial effects, respectively. In Table 8 , the $f^{2}$ column revealed that most of the relations presented a weak effect sizes (i.e. $f^{2}>0.02$ ).

\begin{tabular}{|l|l|l|l|l|l|}
\hline Variables & $\boldsymbol{f}^{2}$ Trust & Effect size & IV & $\boldsymbol{f}^{2}$ BI & Effect size \\
\hline IA & 0.226 & moderate & Trust & 4.891 & substantial \\
\hline IC & 0.027 & weak & & & \\
\hline IQ & 0.007 & - & & & \\
\hline IU & 0.051 & weak & & & \\
\hline
\end{tabular}

Table 8. Effect size 
The result from Table 8 above suggests that the inclusion of an additional path(s) or independent variable(s) has no observable effect on a dependent variable variances. Specifically, in terms of the substantive effects for the behavioural intention towards e-WOM determinants (information adoption, information credibility and information usefulness), the $f^{2}$ is more than 0.02 . Whereas, information quality has $\mathrm{f} 2$ values below 0.02 . This result suggested that the path coefficient $(\beta)$ of information adoption moderated effects on behavioural intention. Reasonably, the weak effect of these paths was made based on their lack of significant impact on the dependent variable (behavioural intention).

\subsection{Mediating Analysis}

The Sobel test [92] was utlised to determine the significance of the mediating effect. It is most widely adopted by researchers employing the PLS-SEM analysis [93]. In this sense, the 1,000 bootstrap estimates of the indirect effects were calculated. If the $\mathrm{z}$-value exceeds 1.96 (at $\mathrm{p}<0.05$ ), the null hypothesis of the strength of the indirect effect of $\mathrm{X}$ on $\mathrm{Y}$ equal to zero, i.e., there is no indirect effect can be rejected [94]. The mediating variable (trust) is introduced into the relationship between information quality, information credibility, information usefulness, information adoption and behavioural intention.

Four hypotheses focused on the mediating effect of trust towards the relationship between information quality $\left(\mathrm{H}_{4 a}\right)$, information credibility $\left(\mathrm{H}_{4 \mathrm{c}}\right)$, information usefulness $\left(\mathrm{H}_{4 \mathrm{c}}\right)$, information adoption $\left(\mathrm{H}_{4 \mathrm{c}}\right)$ and behavioural intention to use the information for their trip planning. Table 9 reports the summary of the analysis.

\begin{tabular}{|l|l|l|l|l|}
\hline & IQ & IC & IU & IA \\
\hline IV > Med Beta & 0.079 & $0.185^{* * *}$ & $0.230^{* * *}$ & $0.476^{* * *}$ \\
\hline Med > DV Beta & $0.912^{* * *}$ & $0.912^{* * *}$ & $0.912^{* * *}$ & $0.912^{* * *}$ \\
\hline IV > Med SE & 0.062 & 0.081 & 0.076 & 0.078 \\
\hline Med > DV SE & 0.013 & 0.013 & 0.013 & 0.013 \\
\hline Sobel test statistic & 1.273 & $2.282^{* * *}$ & $3.023^{* * *}$ & $6.079^{* * *}$ \\
\hline $\begin{array}{l}\text { One-tailed } \\
\text { probability }\end{array}$ & 0.101 & 0.011 & 0.001 & 0.000 \\
\hline $\begin{array}{l}\text { Two-tailed } \\
\text { probability }\end{array}$ & 0.202 & 0.022 & 0.002 & 0.000 \\
\hline $\begin{array}{l}\text { Result } \\
\text { No Notes: } * \mathrm{p}<.\end{array}$ & $\begin{array}{l}\text { Partial } \\
\text { Mediation }\end{array}$ & $\begin{array}{l}\text { Partial } \\
\text { Mediation }\end{array}$ & $\begin{array}{l}\text { Partial } \\
\text { Mediation }\end{array}$ \\
\hline
\end{tabular}

Table 9. Mediating effect analysis via Sobel test

Based on the Sobel test, this study confirms that trust did not mediate the relationship between information credibility and behavioural intention (Sobel test: 1.273). Next, it was found that trust significantly mediated the relationship between information usefulness and behavioural intention (Sobel test: $2.282^{* * *}$ ), and 
information adoption (Sobel test: 6.079***). The introduction of the mediating variable reduces the direct effect between information credibility, information usefulness and information adoption with trust, which leads towards partial mediation effect. Meawnhile, information quality has no mediating effect on trust (Sobel test: 1.273). From the results of the direct effect model, it shows that that the mediating effect of trust exists partially between the relationship of information credibility, information usefulness and information adoption and behavioural intention.

\section{Discussion}

The purpose of this study is to identify which e-WOM attributes affect travellers' trust and behavioural intention. The outcome of this study underlined the significant influence of e-WOM on consumer behaviour. There are four determinants of e-WOM that can substantially infuence consumer's behavioural intention, which are information quality, information credibility, information usefulness and information adoption. Notably, various researchers confirmed that information quality is a predictor of consumers' behavioural intention [11, 19, 57, 64]. However, this study also found the information quality failure to discern the travellers behavioural intention. Conspicuously, Park et al. [39] stated that information quality is the least important of e-WOM determinants. In the meantime, among all four dimensions, information credibility was determined as the strongest contribution in affecting the travellers behavioural intention. Awad and Ragowsky [75] suggested that credibility is the major determinant in the consumer's decision proses and can reduce their uncertainty. Meanwhile, other researchers also asserts that information credibility has been critically important because travellers seeks information that can satisfy them $[8$, 40, 57].

This study also confirms that information credibility, information usefulness and information adoption have the strongest effects on travellers trust. The higher the quality of the information provided, the more likely the consumer will trust in the information $[18,72,75]$. Also, Gupta and Harris [64] found that the information usefulness in the online review can assist consumers in building trust in the sources. The possibility for consumers to make a behavioural intention can be increased when the information is useful, and it will enhance their trust in making the decision [18, 35, 70]. A recent study by Casaló et al. [65] and Briñol et al. [66] found that a trustful source will lead online consumers to adopt information with a positive bias. Thus, these findings are consistent with the previous literature stating that e-WOM determinants have a significant relationship with travellers trust [65-66. 72].

Moreover, this study found that trust has a significant relationship with a travellers behavioural intention. According to Casaló et al. [65], there is a doubt in the mind of the consumers, which affects the sense of curiosity. Hence, to minimise the risks taken as travellers, Yoo et al. [95] revealed that travellers have intensively used the online review to plan their trips, and they trust e-WOM more compared to the marketers. Meanwhile, this study found that the influence of e-WOM determinants on consumers' behavioural intention will not be effective if the consumer does not trust e-WOM sharing $[7,18,37,70]$. Chu and Kim [41] proposed trust to be considered as 
an important element to influence the e-WOM and consumer's behavioural intention. This can be supported by the research done by Gefen et al. [68] where travellers will demonstrate their behavioural intention towards if they trust the e-WOM platform and the available information. These findings are consistent with the previous literature on online purchasing behaviour; in which customers' purchase intention was mediated through perceived trust as a necessary mediator $[18,51]$.

\section{Conclusion}

This study developed a comprehensive theoretical model examining the determinants of e-WOM information on TripAdvisor, which influences the tourists' trust and behavioural intention. This study has also highlighted the determinants of e-WOM information that can influence tourist's trust and their behavioural intention in planning their trip. Most importantly, this study has contributed to a major understanding in terms of the impact of e-WOM on social media since there are minimal studies focusing on this area, especially in tourism area.

From a practical perspective's insight, this study has helped marketers by enlightening their understanding of the influence of e-WOM (TripAdvisor's review) on consumer's behavioural intention to plan for the trip. This study offers valuable insights into the contextual form and comparative studies for marketers. This study also helps marketers to understand the most significant determinants that can influence consumer's behaviour in planning their trip. Moreover, false or fake reviews should be avoided on any websites because they could affect the perception and consumer's behavioural intention. Lastly, based on this study's outcome, marketers who matter consumer's first expectation about their service and product should start developing decent e-WOM marketing strategies.

It is indisputable that this study has limitations. As can be seen, this research area is highly potential because the number of travellers who used the reviews in the TripAdvisor has been increasing year by year. This research only focused on TripAdvisor. Future research should include other social media together, instead of only focusing on TripAdvisor. The results may be varying according to different types of social media's review used for travel planning. By making a comparison of different social media websites in the context of e-WOM, it can bring new insights both practically and theoretically. It would be useful if there other explore similar research framework in a much comprehensive study and niche research setting. It is also suggested for the future researchers to determine the external aspects such as conduction interview with tourists in understanding the impact of e-WOM in organising and planning a trip.

\section{Acknowledgements}

The authors whose names are listed certify that they have NO affiliations with or involvement in any organisation or entity with any financial interest or non-financial interest in the subject matter or materials discussed in this manuscript. 
The researchers would like to acknowledge the Ministry of Education, Malaysia for funding this study through the Fundamental Research Grant Scheme (FRGS): 600IRMI/FRGS 5/3 (468/2019)

\section{References}

[1] I. Erkan and C. Evans, "The influence of eWOM in social media on consumers' purchase intentions: An extended approach to information adoption," Computers in Human Behavior, vol. 61, pp. 47-55, 2016.

[2] A. M. Kaplan and M. Haenlein, "Users of the world, unite! The challenges and opportunities of Social Media," Business Horizons, vol. 53, pp. 59-68, 2010.

[3] G. Prendergast, D. Ko, and V. Y. Siu Yin, "Online word of mouth and consumer purchase intentions," International Journal of Advertising, vol. 29, pp. 687-708, 2010.

[4] Y.-C. Chang, C.-H. Ku, and C.-H. Chen, "Social media analytics: Extracting and visualizing Hilton hotel ratings and reviews from TripAdvisor," International Journal of Information Management, vol. 48, pp. 263-279, 2019.

[5] M. Trusov, A. V. Bodapati, and R. E. Bucklin, "Determining influential users in internet social networks," Journal of Marketing Research, vol. 47, pp. 643-658, 2010.

[6] Q. Ye, R. Law, and B. Gu, "The impact of online user reviews on hotel room sales," International Journal of Hospitality Management, vol. 28, pp. 180-182, 2009.

[7] R. Ladhari and M. Michaud, "eWOM effects on hotel booking intentions, attitudes, trust, and website perceptions," International Journal of Hospitality Management, vol. 46, pp. 36-45, 2015.

[8] J. K. Ayeh, N. Au, and R. Law, "“Do we believe in TripAdvisor?" Examining credibility perceptions and online travelers' attitude toward using user-generated content," Journal of Travel Research, vol. 52, pp. 437-452, 2013.

[9] D. Buhalis and R. Law, "Progress in information technology and tourism management: 20 years on and 10 years after the Internet-The state of eTourism research," Tourism Management, vol. 29, pp. 609-623, 2008.

[10] C. W. Yoo, G. L. Sanders, and J. Moon, "Exploring the effect of e-WOM participation on e-Loyalty in e-commerce," Decision Support Systems, vol. 55, pp. 669-678, 2013. 
[11] R. Filieri, "What makes online reviews helpful? A diagnosticity-adoption framework to explain informational and normative influences in e-WOM," Journal of Business Research, vol. 68, pp. 1261-1270, 2015.

[12] S. Melián-González, J. Bulchand-Gidumal, and B. González LópezValcárcel, "Online customer reviews of hotels: As participation increases, better evaluation is obtained," Cornell Hospitality Quarterly, vol. 54, pp. 274-283, 2013.

[13] S. Bambauer-Sachse and S. Mangold, "Brand equity dilution through negative online word-of-mouth communication," Journal of Retailing and Consumer Services, vol. 18, pp. 38-45, 2011.

[14] J. Kietzmann and A. Canhoto, "Bittersweet! Understanding and managing electronic word of mouth," Journal of Public Affairs, vol. 13, pp. 146-159, 2013.

[15] X. Wang, C. Yu, and Y. Wei, "Social media peer communication and impacts on purchase intentions: A consumer socialization framework," Journal of Interactive Marketing, vol. 26, pp. 198-208, 2012.

[16] J. Lee, D.-H. Park, and I. Han, "The effect of negative online consumer reviews on product attitude: An information processing view," Electronic Commerce Research and Applications, vol. 7, pp. 341-352, 2008.

[17] F. M. Zahedi and J. Song, "Dynamics of trust revision: Using health infomediaries," Journal of Management Information Systems, vol. 24, pp. 225-248, 2008.

[18] H. Alhulail, M. Dick, and A. Abareshi, "The Influence of Word of Mouth on Customer Loyalty to Social Commerce Websites: Trust as a Mediator," in International Conference of Reliable Information and Communication Technology, 2018, pp. 1025-1033.

[19] A. I. Nicolaou and D. H. McKnight, "Perceived information quality in data exchanges: Effects on risk, trust, and intention to use," Information Systems Research, vol. 17, pp. 332-351, 2006.

[20] S. Ludwig, K. De Ruyter, M. Friedman, E. C. Brüggen, M. Wetzels, and G. Pfann, "More than words: The influence of affective content and linguistic style matches in online reviews on conversion rates," Journal of Marketing, vol. 77, pp. 87-103, 2013.

[21] A. I. Canhoto and M. Clark, "Customer service 140 characters at a time: The users' perspective," Journal of Marketing Management, vol. 29, pp. 522-544, 2013.

[22] J. Knoll and R. Proksch, "Why we watch others' responses to online advertising-investigating users' motivations for viewing user-generated content in the context of online advertising," Journal of Marketing Communications, vol. 23, pp. 400-412, 2017. 
[23] E. Severi, K. C. Ling, and A. Nasermoadeli, "The impacts of electronic word of mouth on brand equity in the context of social media," International Journal of Business and Management, vol. 9, pp. 84-96, 2014.

[24] A. Toder-Alon, F. F. Brunel, and S. Fournier, "Word-of-mouth rhetorics in social media talk," Journal of Marketing Communications, vol. 20, pp. 4264, 2014.

[25] S. M. Mudambi and D. Schuff, "What makes a helpful review? A study of customer reviews on Amazon. com," MIS Quarterly, vol. 34, pp. 185-200, 2010 .

[26] F. Zhu and X. Zhang, "Impact of online consumer reviews on sales: The moderating role of product and consumer characteristics," Journal of Marketing, vol. 74, pp. 133-148, 2010.

[27] A. Ghose and P. G. Ipeirotis, "Estimating the helpfulness and economic impact of product reviews: Mining text and reviewer characteristics," IEEE Transactions on Knowledge and Data Engineering, vol. 23, pp. 1498-1512, 2010.

[28] R. A. King, P. Racherla, and V. D. Bush, "What we know and don't know about online word-of-mouth: A review and synthesis of the literature," Journal of Interactive Marketing, vol. 28, pp. 167-183, 2014.

[29] S. Sen and D. Lerman, "Why are you telling me this? An examination into negative consumer reviews on the web," Journal of interactive marketing, vol. 21, pp. 76-94, 2007.

[30] B. Bickart and R. M. Schindler, "Internet forums as influential sources of consumer information," Journal of Interactive Marketing, vol. 15, pp. 3140, 2001.

[31] W. Duan, B. Gu, and A. B. Whinston, "Do online reviews matter?-An empirical investigation of panel data," Decision Support Systems, vol. 45, pp. 1007-1016, 2008.

[32] E. Piccinini, R. W. Gregory, and L. M. Kolbe, "Changes in the producerconsumer relationship-towards digital transformation," Changes, vol. 3, pp. 1634-1648, 2015.

[33] P. Sorce, V. Perotti, and S. Widrick, "Attitude and age differences in online buying," International Journal of Retail \& Distribution Management, vol. 33, pp. 122-132, 2005.

[34] S. M. Forsythe and B. Shi, "Consumer patronage and risk perceptions in Internet shopping," Journal of Business research, vol. 56, pp. 867-875, 2003. 
[35] A. Díaz, M. Gómez, and A. Molina, "A comparison of online and offline consumer behaviour: An empirical study on a cinema shopping context," Journal of Retailing and Consumer services, vol. 38, pp. 44-50, 2017.

[36] D. M. Boyd and N. B. Ellison, "Social network sites: definition, history, and scholarship," IEEE Engineering Management Review, vol. 38, pp. 1631, 2010.

[37] R. Filieri, S. Alguezaui, and F. McLeay, "Why do travelers trust TripAdvisor? Antecedents of trust towards consumer-generated media and its influence on recommendation adoption and word of mouth," Tourism Management, vol. 51, pp. 174-185, 2015.

[38] Á. Herrero, H. San Martín, and J. M. Hernández, "How online search behavior is influenced by user-generated content on review websites and hotel interactive websites," International Journal of Contemporary Hospitality Management, vol. 27, pp. 1573-1597, 2015.

[39] D.-H. Park, J. Lee, and I. Han, "The effect of on-line consumer reviews on consumer purchasing intention: The moderating role of involvement," International Journal of Electronic Commerce, vol. 11, pp. 125-148, 2007.

[40] M. Y. Cheung, C. Luo, C. L. Sia, and H. Chen, "Credibility of electronic word-of-mouth: Informational and normative determinants of on-line consumer recommendations," International Journal of Electronic Commerce, vol. 13, pp. 9-38, 2009.

[41] S.-C. Chu and Y. Kim, "Determinants of consumer engagement in electronic word-of-mouth (eWOM) in social networking sites," International Journal of Advertising, vol. 30, pp. 47-75, 2011.

[42] K. L. Xie, C. Chen, and S. Wu, "Online consumer review factors affecting offline hotel popularity: evidence from tripadvisor," Journal of Travel \& Tourism Marketing, vol. 33, pp. 211-223, 2016.

[43] L. Xia and N. N. Bechwati, "Word of mouse: the role of cognitive personalization in online consumer reviews," Journal of Interactive Advertising, vol. 9, pp. 3-13, 2008.

[44] S. C. Yang, W. C. Hung, K. Sung, and C. K. Farn, "Investigating initial trust toward e-tailers from the elaboration likelihood model perspective," Psychology \& Marketing, vol. 23, pp. 429-445, 2006.

[45] Y. Gvili and S. Levy, "Antecedents of attitudes toward eWOM communication: differences across channels," Internet Research, vol. 26, pp. 1030-1051, 2016.

[46] R. A. Owusu, C. M. Mutshinda, I. Antai, K. Q. Dadzie, and E. M. Winston, "Which UGC features drive web purchase intent? A spike-and-slab Bayesian Variable Selection Approach," Internet Research, vol. 26, pp. 2237, 2016. 
[47] E. McGinnies and C. D. Ward, "Better liked than right: Trustworthiness and expertise as factors in credibility," Personality and Social Psychology Bulletin, vol. 6, pp. 467-472, 1980.

[48] G. R. Miller and J. Baseheart, "Source trustworthiness, opinionated statements, and response to persuasive communication," 1969.

[49] S. W. Litvin, R. E. Goldsmith, and B. Pan, "Electronic word-of-mouth in hospitality and tourism management," Tourism Management, vol. 29, pp. 458-468, 2008.

[50] L. C. Tidwell and J. B. Walther, "Computer-mediated communication effects on disclosure, impressions, and interpersonal evaluations: Getting to know one another a bit at a time," Human Communication Research, vol. 28, pp. 317-348, 2002.

[51] L. M. Willemsen, P. C. Neijens, F. Bronner, and J. A. De Ridder, "“Highly recommended!" The content characteristics and perceived usefulness of online consumer reviews," Journal of Computer-Mediated Communication, vol. 17, pp. 19-38, 2011.

[52] M. K. Lee and E. Turban, "A trust model for consumer internet shopping," International Journal of electronic commerce, vol. 6, pp. 75-91, 2001.

[53] D. H. McKnight and N. L. Chervany, "What trust means in e-commerce customer relationships: An interdisciplinary conceptual typology," International Journal of Electronic Commerce, vol. 6, pp. 35-59, 2001.

[54] J. W. Che, C. M. Cheung, and D. R. Thadani, "Consumer purchase decision in Instagram stores: The role of consumer trust," in Proceedings of the 50th Hawaii International Conference on System Sciences, 2017.

[55] J. A. Yeap, J. Ignatius, and T. Ramayah, "Determining consumers' most preferred eWOM platform for movie reviews: A fuzzy analytic hierarchy process approach," Computers in Human Behavior, vol. 31, pp. 250-258, 2014.

[56] E.-J. Lee and S. Y. Shin, "When do consumers buy online product reviews? Effects of review quality, product type, and reviewer's photo," Computers in Human Behavior, vol. 31, pp. 356-366, 2014.

[57] C. Luo, X. R. Luo, L. Schatzberg, and C. L. Sia, "Impact of informational factors on online recommendation credibility: The moderating role of source credibility," Decision Support Systems, vol. 56, pp. 92-102, 2013.

[58] C. M. Cheung and D. R. Thadani, "The impact of electronic word-ofmouth communication: A literature analysis and integrative model," Decision Support Systems, vol. 54, pp. 461-470, 2012. 
[59] S. W. Sussman and W. S. Siegal, "Informational influence in organizations: An integrated approach to knowledge adoption," Information Systems Research, vol. 14, pp. 47-65, 2003.

[60] M. Khammash and G. H. Griffiths, "'Arrivederci CIAO. com, Buongiorno Bing. com'-Electronic word-of-mouth (eWOM), antecedences and consequences," International Journal of Information Management, vol. 31, pp. 82-87, 2011.

[61] Y. Y. Chan and E. W. Ngai, "Conceptualising electronic word of mouth activity: An input-process-output perspective," Marketing Intelligence \& Planning, vol. 29, pp. 488-516, 2011.

[62] C. M. Cheung, M. K. Lee, and N. Rabjohn, "The impact of electronic word-of-mouth: The adoption of online opinions in online customer communities," Internet Research, vol. 18, pp. 229-247, 2008.

[63] C.-F. Chiang and S. S. Jang, "The effects of perceived price and brand image on value and purchase intention: Leisure travelers' attitudes toward online hotel booking," Journal of Hospitality \& Leisure Marketing, vol. 15, pp. 49-69, 2007.

[64] P. Gupta and J. Harris, "How e-WOM recommendations influence product consideration and quality of choice: A motivation to process information perspective," Journal of Business Research, vol. 63, pp. 1041-1049, 2010.

[65] L. V. Casaló, C. Flavián, and M. Guinalíu, "Understanding the intention to follow the advice obtained in an online travel community," Computers in Human Behavior, vol. 27, pp. 622-633, 2011.

[66] P. Brinol, R. E. Petty, C. Valle, D. D. Rucker, and A. Becerra, "The effects of message recipients' power before and after persuasion: a self-validation analysis," Journal of Personality and Social Psychology, vol. 93, p. 1040, 2007.

[67] D. H. McKnight, V. Choudhury, and C. Kacmar, "Developing and validating trust measures for e-commerce: An integrative typology," Information systems research, vol. 13, pp. 334-359, 2002.

[68] D. Gefen, E. Karahanna, and D. W. Straub, "Trust and TAM in online shopping: an integrated model," MIS quarterly, vol. 27, pp. 51-90, 2003.

[69] M. Koufaris and W. Hampton-Sosa, "The development of initial trust in an online company by new customers," Information \& management, vol. 41, pp. 377-397, 2004.

[70] Y. Kim and R. A. Peterson, "A Meta-analysis of Online Trust Relationships in E-commerce," Journal of Interactive Marketing, vol. 38, pp. 44-54, 2017. 
[71] M. Fishbein and I. Ajzen, "Belief, attitude, intention, and behavior: An introduction to theory and research," 1977.

[72] M. Brengman and F. P. Karimov, "The effect of web communities on consumers' initial trust in B2C e-commerce websites," Management Research Review, vol. 35, pp. 791-817, 2012.

[73] L.-Y. Pan and J.-S. Chiou, "How much can you trust online information? Cues for perceived trustworthiness of consumer-generated online information," Journal of Interactive Marketing, vol. 25, pp. 67-74, 2011.

[74] K. H. Yoo and U. Gretzel, "Comparison of deceptive and truthful travel reviews," in ENTER, 2009, pp. 37-47.

[75] N. F. Awad and A. Ragowsky, "Establishing trust in electronic commerce through online word of mouth: An examination across genders," Journal of Management Information Systems, vol. 24, pp. 101-121, 2008.

[76] J. Romaniuk and B. Sharp, "Measuring brand perceptions: Testing quantity and quality," Journal of Targeting, Measurement and Analysis for Marketing, vol. 11, pp. 218-229, 2003.

[77] K. S. Fam, T. Foscht, and R. D. Collins, "Trust and the online relationship — an exploratory study from New Zealand," Tourism Management, vol. 25, pp. 195-207, 2004.

[78] U. Sekaran and R. Bougie, "Research Methods For Business, A Skill Building Approach, John Willey \& Sons," Inc. New York, 2003.

[79] R. V. Krejcie and D. W. Morgan, "Determining sample size for research activities," Educational and Psychological Measurement, vol. 30, pp. 607$610,1970$.

[80] J. E. Bailey and S. W. Pearson, "Development of a tool for measuring and analyzing computer user satisfaction," Management Science, vol. 29, pp. 530-545, 1983.

[81] A. Bryman and E. Bell, "Ethics in business research," Business Research Methods, vol. 7, pp. 23-56, 2011.

[82] J. F. Hair, A. H. Money, P. Samouel, and M. Page, "Research methods for business," Education + Training, 2007.

[83] R. B. Kline, Principles and practice of structural equation modeling: Guilford publications, 2015.

[84] J. F. Hair Jr, G. T. M. Hult, C. Ringle, and M. Sarstedt, A primer on partial least squares structural equation modeling (PLS-SEM): Sage publications, 2016. 
[85] J. F. Hair Jr, M. Sarstedt, L. Hopkins, and V. G. Kuppelwieser, "Partial least squares structural equation modeling (PLS-SEM) An emerging tool in business research," European Business Review, vol. 26, pp. 106-121, 2014.

[86] R. P. Bagozzi and Y. Yi, "On the evaluation of structural equation models," Journal of the academy of marketing science, vol. 16, pp. 74-94, 1988.

[87] W. W. Chin, "The partial least squares approach to structural equation modeling," Modern Methods for Business Research, vol. 295, pp. 295-336, 1998.

[88] C. Fornell and D. F. Larcker, "Structural equation models with unobservable variables and measurement error: Algebra and statistics," ed: SAGE Publications Sage CA: Los Angeles, CA, 1981.

[89] J. Hulland, "Use of partial least squares (PLS) in strategic management research: A review of four recent studies," Strategic Management Journal, vol. 20, pp. 195-204, 1999.

[90] O. Götz, K. Liehr-Gobbers, and M. Krafft, "Evaluation of structural equation models using the partial least squares (PLS) approach," in Handbook of Partial Least Squares, ed: Springer, 2010, pp. 691-711.

[91] R. Hallak and G. Assaker, "Using partial least squares structural equation modeling (PLS-SEM) in tourism research," Management science in hospitality and tourism: Theory, practice, and applications, pp. 99-124, 2016.

[92] M. E. Sobel, "Asymptotic confidence intervals for indirect effects in structural equation models," Sociological methodology, vol. 13, pp. 290312, 1982.

[93] A. F. Hayes, "Beyond Baron and Kenny: Statistical mediation analysis in the new millennium," Communication Monographs, vol. 76, pp. 408-420, 2009.

[94] K. J. Preacher and A. F. Hayes, "SPSS and SAS procedures for estimating indirect effects in simple mediation models," Behavior Research Methods, Instruments, \& Computers, vol. 36, pp. 717-731, 2004.

[95] K. H. Yoo, U. Gretzel, and F. Zach, "Travel opinion leaders and seekers," in ENTER, 2011, pp. 525-535. 